\title{
Reluctance Network Analysis of Wind Power Systems Using Permanent-Magnetic Reluctance Generator
}

\author{
O. Ichinokura, M. Kubota, H. Goto, and K. Nakamura \\ Graduate School of Engineering, Tohoku University, 6-6-05 Aoba Aramaki, Aoba-ku, Sendai, Miyagi 980-8579, Japan
}

\begin{abstract}
Wind power generators are well known as renewable sources of energy and permanent-magnetic reluctance generators are expected to be used for these. Although they can generally be simulated using the finite element method, this is not suitable for complex systems such as wind power generators. We simulated wind power generation using a permanent-magnetic reluctance generator with a DC micro grid system. The results revealed the possibility of implementing a wind power generation system.
\end{abstract}

Key words: permanent-magnetic reluctance generator, wind power generator, magnetic circuit, maximum power tracking control

\section{永久磁石リラクタンスジェネレータを用いた 風力発電システムの磁気回路網による解析}

\author{
一ノ倉 理, 久保田 雅之, 後藤 博樹, 中村 健二
}

東北大学大学院工学研究科, 宮城県仙台市青葉区荒巻字青葉 6-6-05（广 980-8579）

\section{1. はじめに}

近年，地球温暖化一の懸念から，従来利用されてこなかった口 一カルエネルギーを有效利用するため，小型風力発電，小水力発 電などの分散型電源への期待が高まっており，これらに使用され る中容量から小容量の発電機の需要も増大している.

発電機は様々な種類があり，例えば，誘導発電機は構造が簡単 で電力系統との連系も容易であるが，力率と効率が低いという久 点がある，一方，直流励磁同期発電機は，効率ならびに力率は良 いが，スリップリングを有するため構造が複雑になり，中小容量 の発電機には必ずしも適さない，永久磁石同期発電機は保守にも 優孔効率も良いが，高速回転時の機械的強度や，高温環境下での 使用にやや問題がある.

これらに対して筆者らが先に提案した永久磁石リラクタンスジ ェネレータ(1)(2)（以下 PMRG と表記）は，永久磁石を固定子に配 置しているため，耐久性に優机高速回転に適している．さらに冷 却が容易になり，高温環境下の使用も可能になると考えられる.

また, PMRG は回転子位置検出器や励磁用電源も不要なため, 極 めて簡単な構成で発電を行うことが可能である.

発電機の解析手法として，一般に計算精度の高い有限要素法解 析 (以下, FEM と略記) を用いた最適化が行われている. しかし， FEM は制御回路や電気回路部分を含む解析において回路シミュレ 一夕との連携解析が難しく, 風力発電システムのような発電機以 外にも電気回路，制御回路，機械的駆動部分を持つシステムの解 析に不向きである。

本稿では, PMRG の磁気回路モデルを導出し，発電特性を算定 した. さらに, この発電機を持つ風力発電システムについて汎用 の電気回路シミュレータである Simplorer を用いてシミュレーショ ンを行ったので報告する.

\section{PMRG の基本構成と発電原理}

PMRG は同期発電機の一種であるが，固定子側に永久磁石（界 磁）と電機子巻線の双方が配置された構造を有する点が，従来の 回転界磁形あるいは回転電機子形同期発電機と異なる。 これによ りブラシやスリップリングが不要となり，回転子に永久磁石を使 用しないため，極めて保守性が高く，堅牢で高速回転に適した発 電機が実現できるものと考えられる. Fig. 1 にPMRG の構造と緒 元を示寸. Fig. 1のようにPMRG の固定子鉄心には，二つの永久 磁石が埋め込まれている．回転子は突極形状の無方向性電磁鋼板 を積層して構成される. 回転子が外力によって駆動されると, 固 定子と回転子間のギャップの磁気抵抗が周期的に変化するため, 固定子巻線と鎖交する磁束も周期的に変化する. したがって, 固 定子卷線に電圧が誘起され，接続された負荷に電力が供給される.

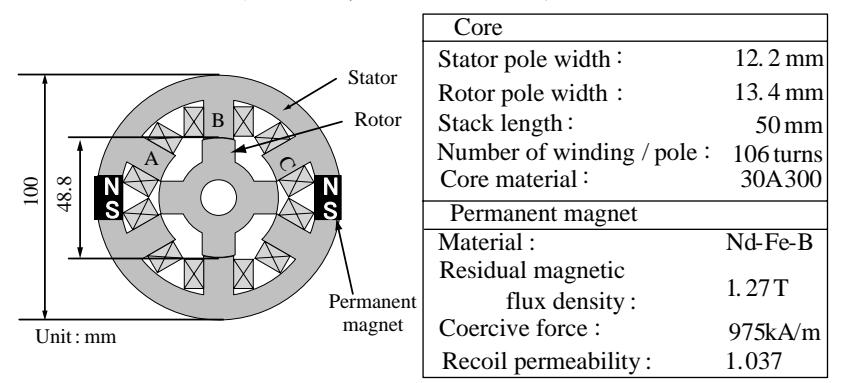

Fig. 1 Structure and specifications of PMRG.

\section{PMRG の磁気回路モデル導出}

\section{1 磁気回路モデルの導出}

Fig. 2 に, PMRGの磁気回路モデルを示寸. 本モデルは, 固定子と回転子間のギャップの磁気抵抗 $R_{g i}(i=\mathrm{a}, \mathrm{b}, \mathrm{c})$, 永久 磁石の内部磁気抵抗 $R_{p}$, 永久磁石との接合面からの漏れ磁 気抵抗 $R_{p l}$, 固定子極からの漏孔磁束 $R_{g l}$, 巻線電流による 起磁力 $N I_{i}$ と永久磁石による起磁力 $F_{p}$ で構成される. ただ し電磁鋼板部分の非線形性は考慮しないものとした.

まず，初めに Fig. 2 の斜線部のような閉路を流れる磁束 について考える事により固定子と回転子のギャップの磁気 
抵抗を求める.この時コイルに負荷は接続せず，巻き線に よる起磁力は発生しない. $R_{g i}$ は極が対向状態の時は小さ く, 非対向状態の時は大きいというように回転子の位置に よって周期的に変動する事が予想される. そこでまず FEM により発電機が無負荷状態で, 回転子角が様々な位置にあ る時の回転子極と磁石内部を流れる磁束 $\phi_{i}(\theta)$ と $\phi_{p}(\theta)$ をそ れぞれ求める. 次に永久磁石による起磁力 $F_{p}$ は磁石長 $l_{m}$ と磁石のリコイル比 $H_{c}$ を用いて次式で与えられる.

$$
F_{p}=H_{c} l_{m} \text {. }
$$

また, 永久磁石の比透磁率を $\mu \mathrm{r}$, 真空中の透磁率を $\mu_{0}$ と し，磁石の断面積を $S$ とすると $R_{p}$ は次のように表す事が できる.

$$
R_{p}=\frac{l_{m}}{\mu_{r} \mu_{0} S} .
$$

閉路において, 以下の式が成り立つ.

$$
F_{p}=\phi_{i}(\theta) \times 2 R_{g i}+\phi_{p}(\theta) R_{p} .
$$

$R_{g i}$ について整理すると次式のように表せる.

$$
R_{g i}(\theta)=\frac{F_{p}-\phi_{p}(\theta) R_{p}}{2 \phi_{i}(\theta)} .
$$

(4)式において, 既知の值 $F_{p}, R_{p}$ と FEM によって得られた 磁石内部を流れる磁束 $\phi_{p}(\theta)$ と極を流れる磁束 $\phi_{i}(\theta)$ を利用 して $R_{g r}(\theta)$ を求めた.

同様にして, FEM による解析結果を利用し, 未知の磁気 抵抗 $R_{p l}, R_{g l}$ を求めた。

\section{2 RNA と FEM による算定結果の比較}

Fig. 3 に, PMRG の回転数 $4800 \mathrm{rpm}$ で一定とした時の 発電出力特性と電圧特性について FEM と磁気回路による シミュレーション結果を示す. FEM の解析については非線 形磁気特性を考慮している. 負荷電流が約 $2.5 \mathrm{~A}$ 以下の領 域においては FEM と磁気回路の算定結果は良好に一致し ているが，それ以上の領域では，FEM の結果が磁気回路モ デルのより大きくなっている．この理由を以下のように考 察する.まず, この発電機は, 電機子電流により発生する 磁束が大きくなると永久磁石からの磁束を妨げ, 固定子極 を流れる磁束が小さくなり誘起電圧が低くなる特徵を有し ている. さらに, FEM 解析では, 電機子電流によって発生 する磁束によって固定子極で磁気飽和が起こることが確認 されている. これらの事から, 固定子極を流れる総磁束量 が FEM の方が大きくなり, 出力電圧と電力が大きくなっ たと考えられる.

Fig. 4 に回転数 $4800 \mathrm{rpm}$ 一定時における無負荷時の出 力電圧波形を示す. また, この時の固定子極を流れる磁束 を Fig. 5 に示す. 図中の A, B, C は Fig. 1 に示す固定子 極を表している. どちらも，FEM と磁気回路で定性的, 定 量的に良好な一致が見られる。

以上より, PMRGの解析に磁気回路を用いて発電機特性 を再現できる事がわかる.

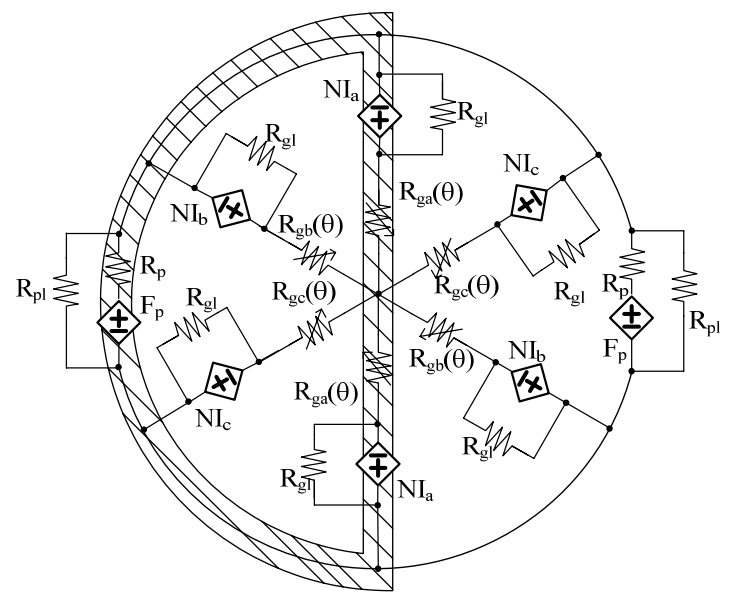

Fig. 2 Magnetic circuit model of PMRG.

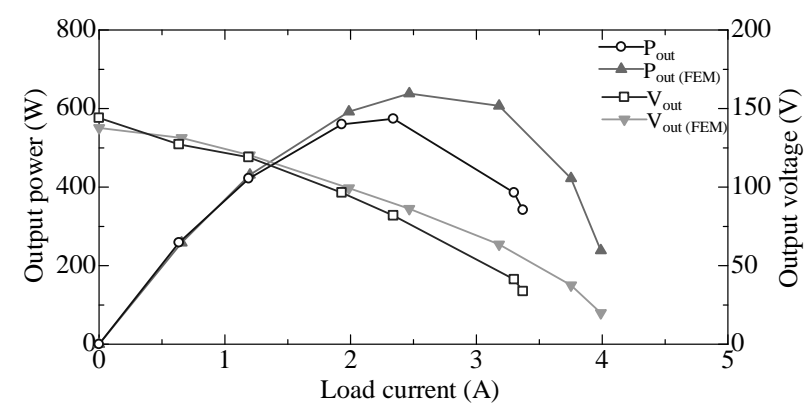

Fig. 3 Generation characteristics.

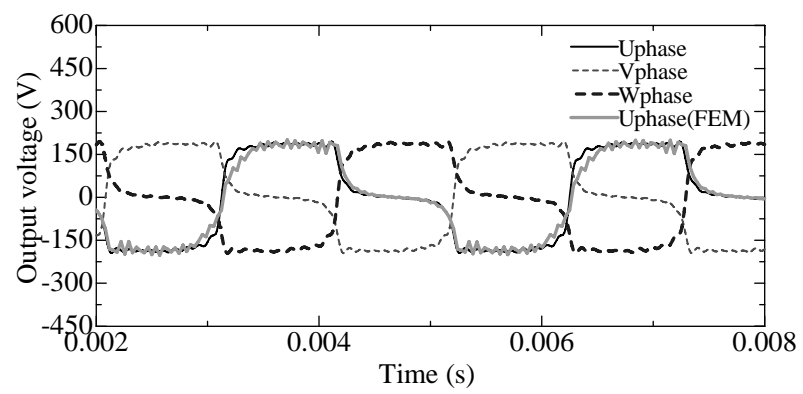

Fig. 4 Induced voltage with no load.

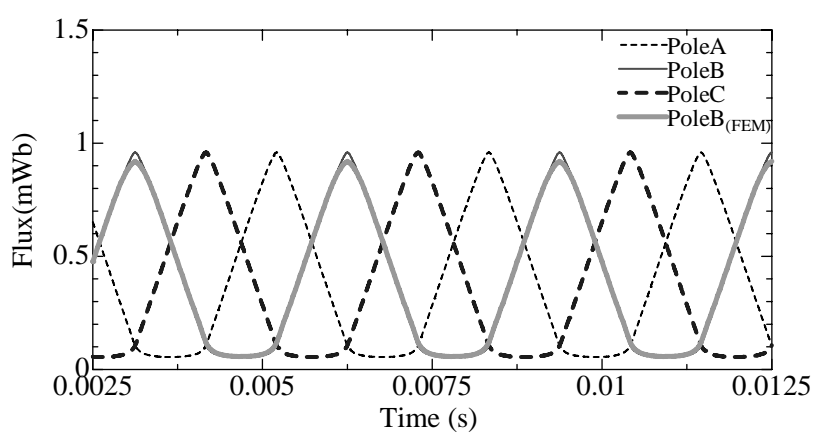

Fig. 5 Flux through stator poles at no load.

\section{4. 風車特性}

検討した風車の外観を Fig. 6 に示す．この風車は三枚の ブレードを持つプロペラ型風車である.

一般に, 風車の受ける風の運動エネルギー $E_{w}$ は次式で表 せる。 


$$
E_{w}=\frac{1}{2} \rho \pi R^{2} V_{w}^{3}
$$

ここで， $V_{W}$ は風速， $R$ は風車半径， $\rho$ は空気の密度である. 風車が発電機に与える機械出力 $P_{W}$ は(6)式のように, 出力 係数 $C_{p}$ を乗じることにより表す.

$$
P_{w}=C_{p} E_{w}=\frac{1}{2} C_{p} \rho \pi R^{2} V_{w}^{3} .
$$

風車トルク $T_{W}$ は風車出力 $P_{W}$ を回転数 $\omega_{m}$ で割ったもので あるから，次のように与えられる。

$$
T_{w}=\frac{P_{w}}{\omega_{m}}=\frac{1}{2} \frac{C_{p} \rho \pi R^{2} V_{w}^{3}}{\omega_{m}} .
$$

ここで, 翼端速度 $R \omega_{m}$ と風速 $V_{W}$ との比は周速比 $\lambda$ と呼ば れ，次のように定義される。

$$
\lambda=\frac{R \omega_{m}}{V_{w}} .
$$

（7)式を周速比 $\lambda$ 用いて整理すると，

$$
T_{w}=\frac{1}{2} C_{p} \frac{V_{w}}{R \omega_{m}} \rho \pi R^{3} V_{w}^{2}=\frac{1}{2} \frac{C_{p}}{\lambda} \rho \pi R^{3} V_{w}^{2} .
$$

となる。

$C_{p}$ は周速比 $\lambda$ の関数であり, 風車の形状により決定され る. 本稿では, 出力係数は周速比の三次関数として次のよ うに近似した。

$$
C_{p}=a_{1} \lambda^{3}+a_{2} \lambda^{2}+a_{3} \lambda .
$$

各係数は風車の実機の特性を参考にし， $a_{1}=-1.6 \times 10^{-3}, a_{2}=$ $1.9 \times 10^{-2}, a_{3}=1.0 \times 10^{-4}$ とした.

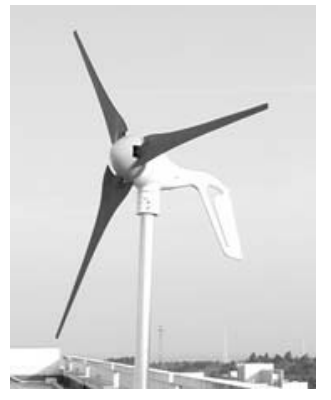

Fig. 6 Structure of windmill.

\section{5. 最大出力追従制御}

（6)式に(10)式，(8)式を代入すると風車出力 $P_{W}$ は以下の ように与えられる。

$$
P_{w}=\frac{1}{2} \rho \pi R^{3} V_{w}^{2}\left(a_{1} R^{2} \frac{\omega_{m}^{3}}{V_{w}^{2}}+a_{2} R \frac{\omega_{m}^{2}}{V_{w}}+a_{3} \omega_{m}\right) .
$$

これより, 風車出力は風速の二乗と回転速度の三次関数の 積となることがわかる.この関係を Fig. 7 に示す. 図より, 風速が一定であっても, 風車の回転速度によって, 出力が 大きく変化することがわかる，また，風速により，風車の 回転速度の最大值が存在し, それ以上の回転数においては 安定した制御ができないことが予想される。
そこで，一般的にそれぞれの風速に応じて風車回転速度 $\omega_{m}$ を最適にすることにより，最大出力追従制御を行う．回 転速度を変化させるには，発電機の励磁を制御するか，電 流を制御してトルクを調整する必要がある.

このような場合において，あらかじめ，風車の出力係数 と風速，発電機のトルク-電流特性がわかっていれば，（11） 式より最適な回転速度を計算し，(9)式からそのときの風車 トルクを計算し，発電機のトルク-電流特性から電流を計算 してチョッパの制御を行うことができる。しかし，これに は風速計や電流センサ，さらに多くのパラメータが必要で あるため, コストがかかる上，経年劣化などのパラメータ 変動にも弱い.

これに対し，山登り法と呼ばれる方法が多く利用されて いる(3). 山登り法の原理を Fig. 8 に示す。風速が一定の時 を考える. チョッパの Dutyの值を $\Delta d$ 増加させた時, 検出 した出力電力が増加した場合は Duty の值をさらに $\Delta d$ 増 加させ(図の $\mathrm{A}$ ), 出力が減少した場合には Duty の值を $\Delta d$ 減少させる(図の B)。また, Duty 減少時に検出した出力が 増加した場合には Dutyの值をさら $\Delta d$ 減少させ(図の C), 出力が減少した場合には Duty の值を $\Delta d$ 増加させる(図の D). 以上のような方法で常に出力が増加するように Duty を増減させることで，最大出力点の追従が行われる．また， このとき，風車や発電機のパラメータを用いないために経 年劣化などのパラメータ変動に強いという利点がある.

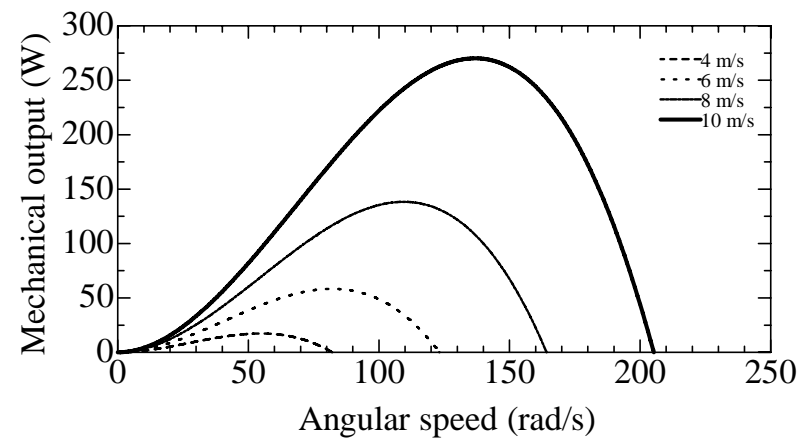

Fig. 7 Relationship between angular speed and mechanical output.

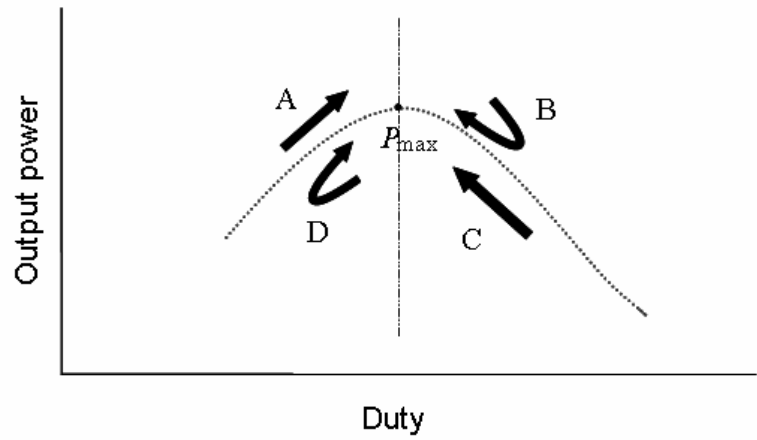

Fig. 8 Principle of hill climbing search. 


\section{6. 解析結果}

Fig. 9 に検討した回路を示す. 本報告では, PMRG を持 つ風力発電機の出力を三相全波整流回路で一旦直流に変換 し，昇降圧チョッパの Duty を山登り法で調整することに より最大出力追従制御を行うシミュレーションを行った。 出力のサンプリング周期は 0.2 秒で Duty の変化量 $\Delta d$ は 0.015 とした。シミュレーションには汎用の電気回路シミ ユレーションである Simplorer を用いた。

風速 $6 \mathrm{~m} / \mathrm{s}$ の一定風速を入力とした. Fig. 10 に昇降圧チ ヨッパの Dutyの変化を示す.また，Fig. 11 に風車の角速 度と機械出力特性を示す. 山登り法によって Duty を変化 させる事により回転速度が適切に制御され, 風速 $6 \mathrm{~m} / \mathrm{s}$ で の最大出力の付近の $56 \mathrm{~W}$ が得られたことがわかる. Fig. 12 に出力電力を示す. 最大 $50 \mathrm{~W}$ の出力が得られた.

以上より, PMRGの磁気回路網モデルを用いた風力発電 システムの動作が確認できる.

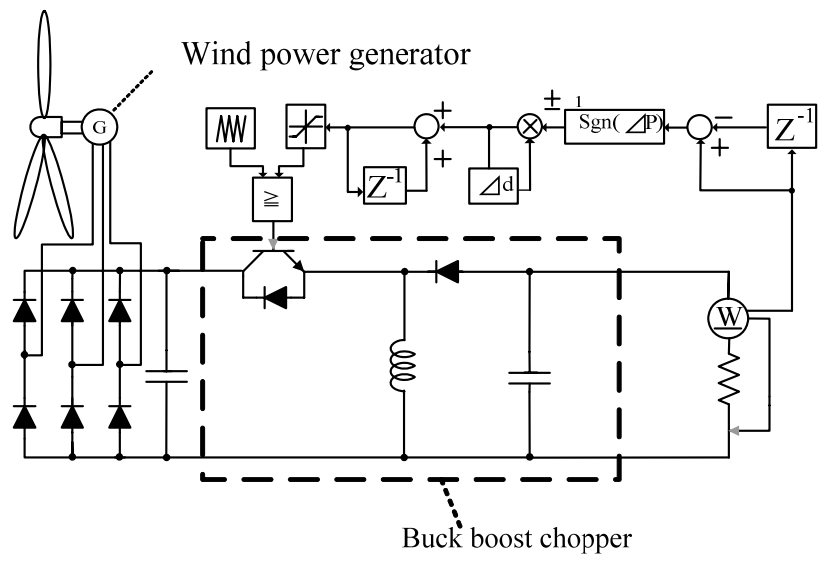

Fig. 9 Circuit used for deliberation.

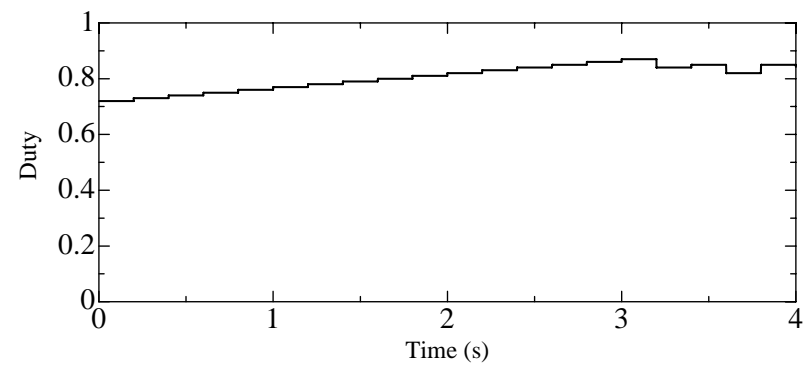

Fig. 10 Waveform of duty ratio.

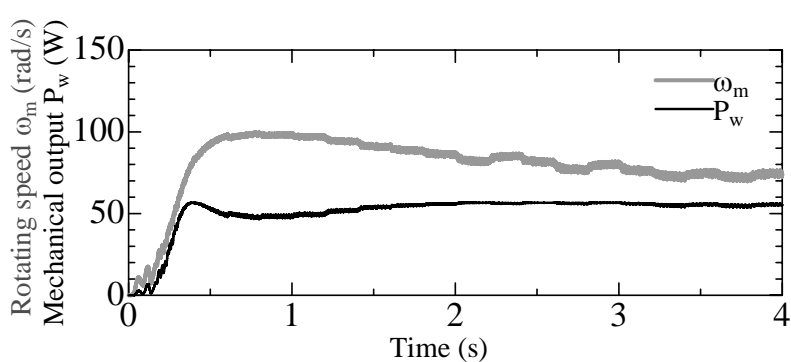

Fig. 11 Mechanical output and rotating speed of wind turbine.

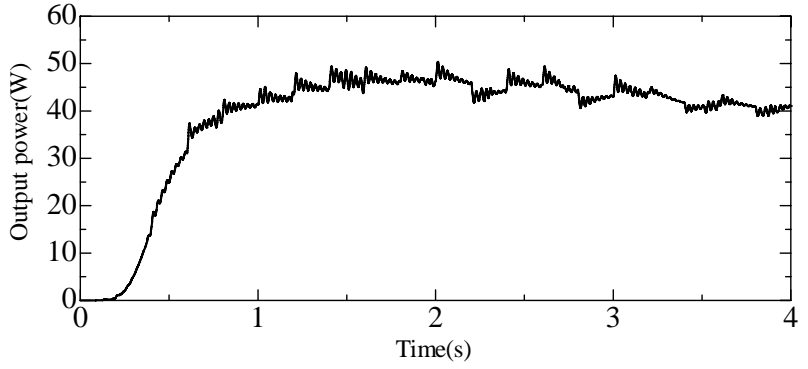

Fig. 12 Output power.

\section{7. まとめ}

PMRG の磁気回路モデルを FEM を用いることによって 作成し, その発電機モデルを利用した風力発電システムに ついて, シミュレーションを行った. 磁気回路の発電機モ デルはFEM と近い結果が得られたので, この発電機が磁 気回路によってモデル化できることがわかった，また，風 力発電システムにおいて PMRG の磁気回路モデルを導入 した際，制御系や電気回路との連成解析が行えることがわ かった。

今後は, 実験による本風力発電システムの有用性の確認 を行う予定である.

なお，本研究の一部は科学研究費補助金基盤研究(B) (19360125)及びに福島県ハイテクプラザ公募型新事業創出 プロジェクト研究事業（新エネルギー用マイクロ発電シス テムの開発）の補助を受け行った。

謝辞 発電機を製作して頂いた(株)日立製作所に感謝致し ます.

\section{References}

1) O. Ichinokura, J. Shida, K. Nakamura, T. Watanabe: "Basic Characteristics of a Reluctance Generator with Permanent Magnets Buried in the Stator Yoke" J. Magn. Soc. Jpn, 29, pp.571 (2005) .

2) O. Ichinokura, T. Ono, K. Nakamura, T. Watanabe: "Theree-Phase Reluctance Generator Using Stator Core with Permanent Magnet” J. Magn. Soc. Jpn, 30, pp. 408-412 (2006).

3) T. Senjyu: "Maximum power Tracking Control for Wind Power System Using Permanent Magnet Synchronous Generator", T. IEE jpn. Vol. 122-B, No. 12, pp.1403-1409, 2002( in Japanese).

2007 年 10 月 2 日受理, 2008 年 2 月 14 日採録 